\title{
Holistic Review and Conceptual Framework for the Drivers of Offsite Construction: A Total Interpretive Structural Modelling Approach
}

\author{
Ibrahim Y. Wuni * (1) and Geoffrey Q. P. Shen \\ Department of Building and Real Estate, The Hong Kong Polytechnic University, Hung Hom 999077, \\ Kowloon Hong Kong SAR, Hong Kong; geoffrey.shen@polyu.edu.hk \\ * Correspondence: ibrahim.wuni@connect.polyu.hk; Tel.: +852-53742907
}

Received: 16 April 2019; Accepted: 7 May 2019; Published: 8 May 2019

\begin{abstract}
The significant ill-performances, challenges, and increasing competition within the construction sector are generating tremendous changes. One such revolution is the transition towards offsite construction (OSC). Although a plethora of studies has expounded the virtues and benefits of the approach, a holistic review and conceptual framework of the drivers of OSC is not well-established. This research draws on a multistage methodological framework of a systematic literature review, plenary discussions, and the total interpretive structural modelling (TISM) approach to build a holistic conceptual framework for the drivers of OSC. A review of 32 empirical studies distributed across four continents resulted in the extraction of 86 drivers. The 86 drivers were grouped into time, cost, quality, productivity, innovative competitiveness, market, sustainability, and policy clusters of drivers drawing on previous classifications in empirical studies. The TISM modeling revealed three hierarchical levels of the drivers, comprising dependent, linkage, and independent drivers. Based on an MICMAC analysis, "innovative competitiveness" and "sustainability" have the highest driving powers and lowest dependences, suggesting their prime significance in the adoption of OSC. Thus, this research provides a broader perspective of the drivers and may help OSC practitioners and policymakers to gain a better understanding of the ecosystem of the drivers.
\end{abstract}

Keywords: conceptual framework; drivers; offsite construction; TISM; review

\section{Introduction}

The global construction sector suffers significant challenges and ill-performances, which are intertwined with processes and products of the traditional onsite construction approach. Notably, the sector is identified as one of the seven most aggressive contributors to climate change because of higher emissions resulting from excessive energy consumption [1]. Global construction activities generate greater proportions of landfill wastes in most countries [2,3]. The sector is also witnessing a rapid shortage, shrinking, and aging of the workforce [4], which engenders a huge risk with sustained manpower considering the global demographic shifts which threaten the sustainability of labor-intensive industries, such as building construction. According to the McKinsey Global Institute [5], construction labor productivity only achieved a marginal $1 \%$ increase per annum within the past two decades. Arcadis [6] reported continuous construction cost escalation in nearly all the major cities of the world. These challenges coupled with the ill-performances collectively engender significant threats to a sustainable future of the construction sector and modern society.

Additionally, construction clients continue to seek timely delivery of projects within budgets without a compromise in quality [7]. Amid the scaling competition, construction companies are required to meet or exceed timelines, quality, and budgets to gain a competitive advantage. To address 
the challenges and keep up with the overwhelming pressure, the construction sector is witnessing a phenomenal change and revolution, albeit in a gradual manner. Construction companies are embracing new business models and countries are pursuing innovative construction technologies. Although the construction sector is conservative and sluggish in the adoption of innovation [8], one overt transition is the growing paradigm shift towards offsite construction (OSC). McKinsey Global Institute [5] argued that a shift to an offsite production system involving mass production, standardization, prefabrication, and modularization has the potential to improve cost performance, schedule, predictability, productivity, and general business performance in the construction sector.

Offsite production [9], offsite manufacture [10], offsite fabrication, modular construction [11], modular integrated construction [12], modern methods of construction [13], industrialized building systems [14], prefabricated construction, systems building, prefabricated prefinished volumetric construction [15], and industrialized construction [16] are region-specific innovative construction techniques in the extant literature and represent OSC in this research, where all or some components of a whole building are manufactured and partially or wholly assembled in a prefabrication factory and then transported to a construction site for final installation. OSC largely involves the production of buildings in an assembly line process, which are trucked to a job site in sections, set in place with cranes, and then assembled to form a complete building. Given the nature of its processes, OSC is identified as a cleaner approach, which improves the construction trade's continuity and workflow productivity [17].

Experiences in countries, such as Singapore [15], United States [18], United Kingdom [19], China [20], Hong Kong [21,22], Australia [4], and Malaysia [23], have established that attainable benefits of OSC include speedy construction, reduced construction waste, improved health and safety, reduced lifecycle cost, certainty and predictability of construction costs, and lower embodied carbon, emissions and environmental impact. Despite the existence of a complex web of barriers, OSC continues to gain attention in the architecture, engineering, and construction industries (AEC). Hon and Pan [12] noted that the promotion of OSC techniques in different countries is driven by diversified policies, practice priorities, and foci. As such, there is a growing body of literature examining the drivers of OSC in many countries. However, a holistic review and conceptual framework for the drivers of OSC is not well-established. Additionally, there is no study that has explicitly explored the interactions among the drivers of OSC and proposed a self-explanatory conceptual framework.

Zakaria et al. [24] reviewed the contextual, behavioral, and structural factors that influence the adoption of industrialized building systems (IBSs), but did not attempt to explore the interactions of the drivers. Particularly, Zakaria et al.'s [24] study would have been more comprehensive if they conceptualized both the benefits and drivers of an IBS as an ecosystem, but fell short of this useful parameter. As such, this research conducts a systematic review of empirical studies on the benefits and drivers of OSC and proposes a self-explanatory conceptual framework using a total interpretive structural modelling (TISM) approach. To accomplish the aim, three research questions warrant critical consideration: (i) What are the drivers of OSC? (ii) How are the drivers of OSC interlinked? (iii) How best can these drivers of OSC be conceptualized as an ecosystem? Consistent with the works of Mao et al. [20], this research argues that the drivers of OSC behave like an ecosystem with interdependences and do not exist in isolation. To demonstrate this assertion, the TISM approach [25] is deployed to build a conceptual framework for the drivers of OSC, mapping their interactions. The rest of the paper is organized as follows. The research methodology is immediately described and justified. Next, results of the holistic literature review and the TISM model of the drivers are presented and discussed. The paper then offers the theoretical and practical implications of the study and draws some conclusions based on the review findings and TISM model.

\section{Research Methodology}

Following the established principles of the TISM approach, the paper draws on a multistage methodological approach [26]. The stages involve a systematic literature review, engagement of 
the opinions of experts (plenary discussion) and building of the TISM model. Figure 1 shows the methodological framework for the paper. The systematic literature review is required to identify the important drivers of OSC and the plenary session is required to establish the interactions between and among the drivers within the TISM model. This paper conceptualizes drivers of OSC to include factors, actions, intervention, and attributes of OSC (including benefits) that motivate, influence, and compel its adoption.

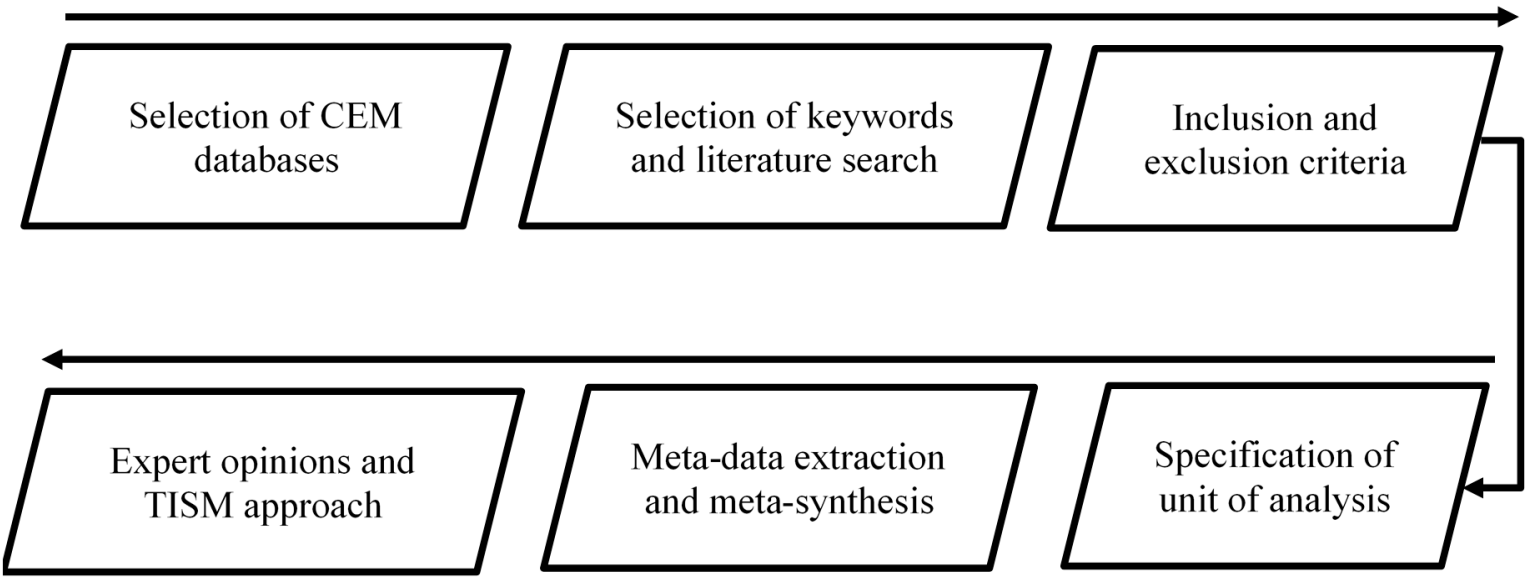

Figure 1. A methodological framework for the study.

\subsection{Systematic Literature Review Protocol}

The first stage in the TISM approach is a comprehensive review of the extant literature $[27,28]$. The paper adopted a comprehensive systematic literature review methodological framework comprising a selection of databases, selection of keywords and literature search, inclusion and exclusion criteria, specification of a unit of analysis, metadata extraction, and synthesis. The authors initiated the systematic literature review with a selection of construction engineering and management (CEM) databases, which index studies relevant to the research. Following the precedents of Xiong et al. [29], the study considered Elsevier's Scopus, Clarivate Analytics' Web of Science, Google Scholar, ASCE library, Taylor and Francis, and Emerald Insight. Representative keywords for "drivers" and "offsite construction" were identified and refined throughout the review process. Drawing on the literature, similar nomenclatures for "drivers", such as "enablers", "factors", "benefits", "merits", and "advantages", including "drivers", were considered. For the case of OSC, similar nomenclatures, such as "offsite construction", "offsite production", "offsite manufacturing", "prefabricated", "prefabrication", "industrialized construction", "systems building", "modern method of construction", "industrialized building systems", "prefabricated prefinished volumetric construction", "modular construction", and "modular integrated construction", were considered. These keywords are not exhaustive but were deemed adequate.

These two sets of keywords were used to conduct structured and unconstrained iterative queries in the specified databases. As of October 2018, a total of 201 articles were retrieved from all the databases. Considering that the study extended beyond four months, the search was repeated immediately prior to submission to retrieve newly published studies. Next, the study specified the inclusion and exclusion criteria to facilitate the screening of the retrieved articles. An article was included if it is an empirical study on the drivers of OSC and published in a quality CEM journal or highly rated conference proceeding. However, an empirical study published in a low-impact journal was included where it contained a well-justified methodological framework. The articles screening process and results followed the Preferred Reporting Items for Systematic Reviews and Meta-Analyses (PRISMA) protocol as shown in Figure 2. 


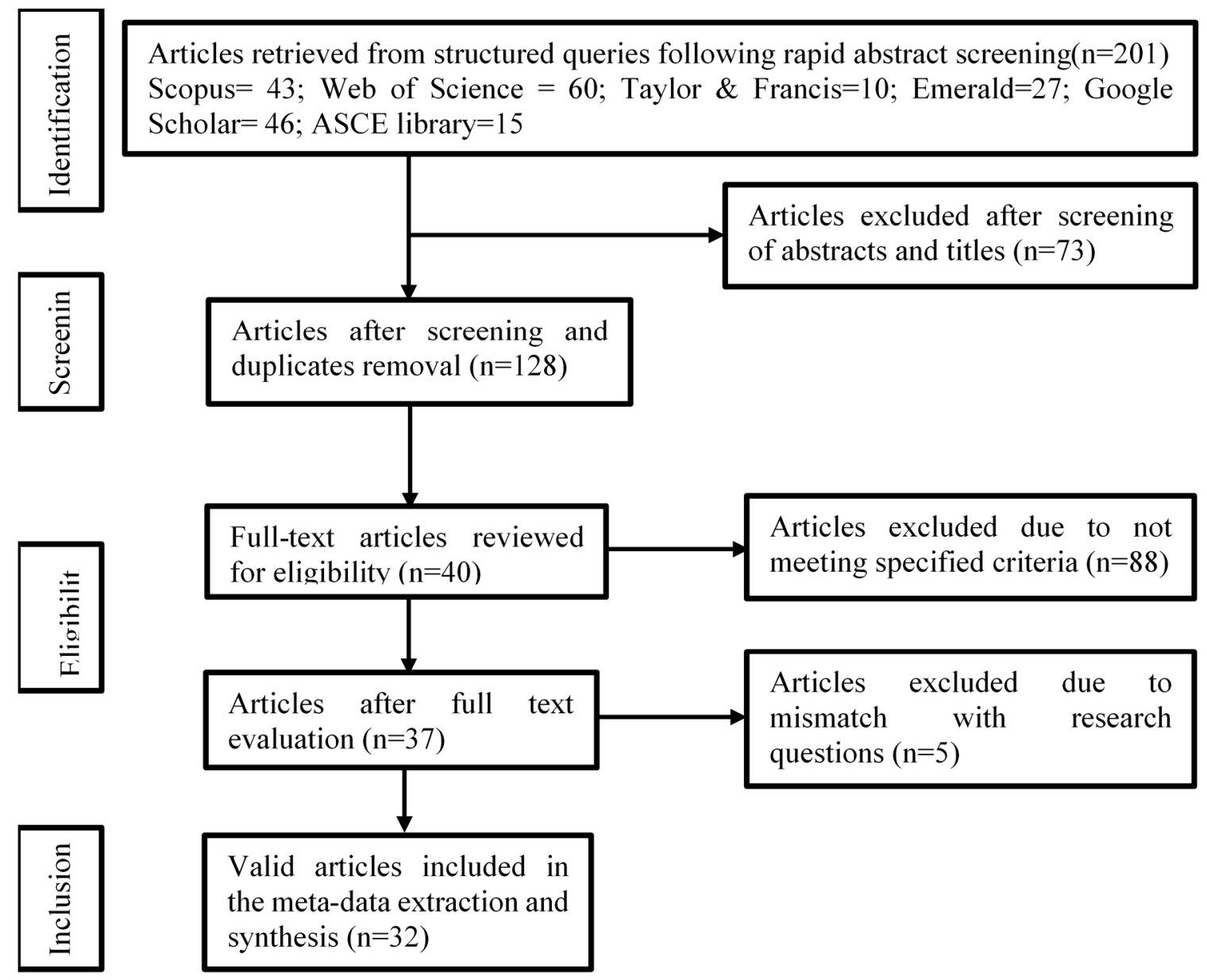

Figure 2. Article screening and evaluation protocol (adapted from Moher et al. [30]).

Following a rapid screening of abstracts and full-text evaluations, 32 articles were deemed valid for inclusion (Figure 2). Albeit small, this sample compares favorably with some published CEM review articles, which used 16 [31] and 27 articles [32]. The sample was also adequate because the articles were distributed across Europe, Asia, Australia, and North America. Based on the research questions, the primary unit of analysis was the "drivers" of OSC. For each article, the researchers extracted and cataloged the drivers. The authors also extracted the context (country) of the study and the engaged stakeholders in each study. After aggregating and synthesizing the extractions, the study found 86 drivers of OSC. Drawing on previous clustering of drivers $[10,20,33]$, the researchers proposed an extended classification framework comprising time performance (D1), cost performance (D2), quality performance (D3), productivity (D4), innovative competitiveness (D5), sustainability (D6), market (D7), and policy (D8) drivers. These clusters and their unit drivers formed the basis for building the conceptual framework using the TISM approach.

\subsection{Total Interpretive Structural Modelling (TISM) Approach}

The TISM approach was adopted to build the conceptual framework for the drivers of OSC to reveal their structure, interactions, and ecosystem (interdependences). The traditional interpretive structural modeling (ISM) approach [34] offers a unique graphical procedure for building the hierarchical structure and dynamic behavior of a complex problem. However, Sushil [25] found that the ISM approach is deficient in explaining the causal relationship and transitive links among the hierarchies within the model.

Thus, the TISM approach was introduced as an innovative extension of the ISM approach to allow for an explicit explanation of the transitive links in the model. TISM draws on graph theory 
and systems-thinking principles [25], offering a unique approach of using directed graphs to build a conceptual framework [26,35]. Considering its capability of mapping the holistic interactions of complex systems [36], TISM is widely used in building conceptual frameworks and theories. Gahana et al. [27] adopted the TISM methodology to build a conceptual framework for the drivers and barriers to integrated sustainable waste management. Shibin et al. [35] used TISM to develop a conceptual framework for the enablers and barriers of a flexible green supply chain. Since the TISM methodology is well-established in other fields, this research adopted the methodology to build a conceptual framework for the drivers of OSC within the CEM research domain. Figure 3 shows the methodological framework of the TISM approach $[25,26,37]$. The major stages of the TISM approach are explained in Section 3.

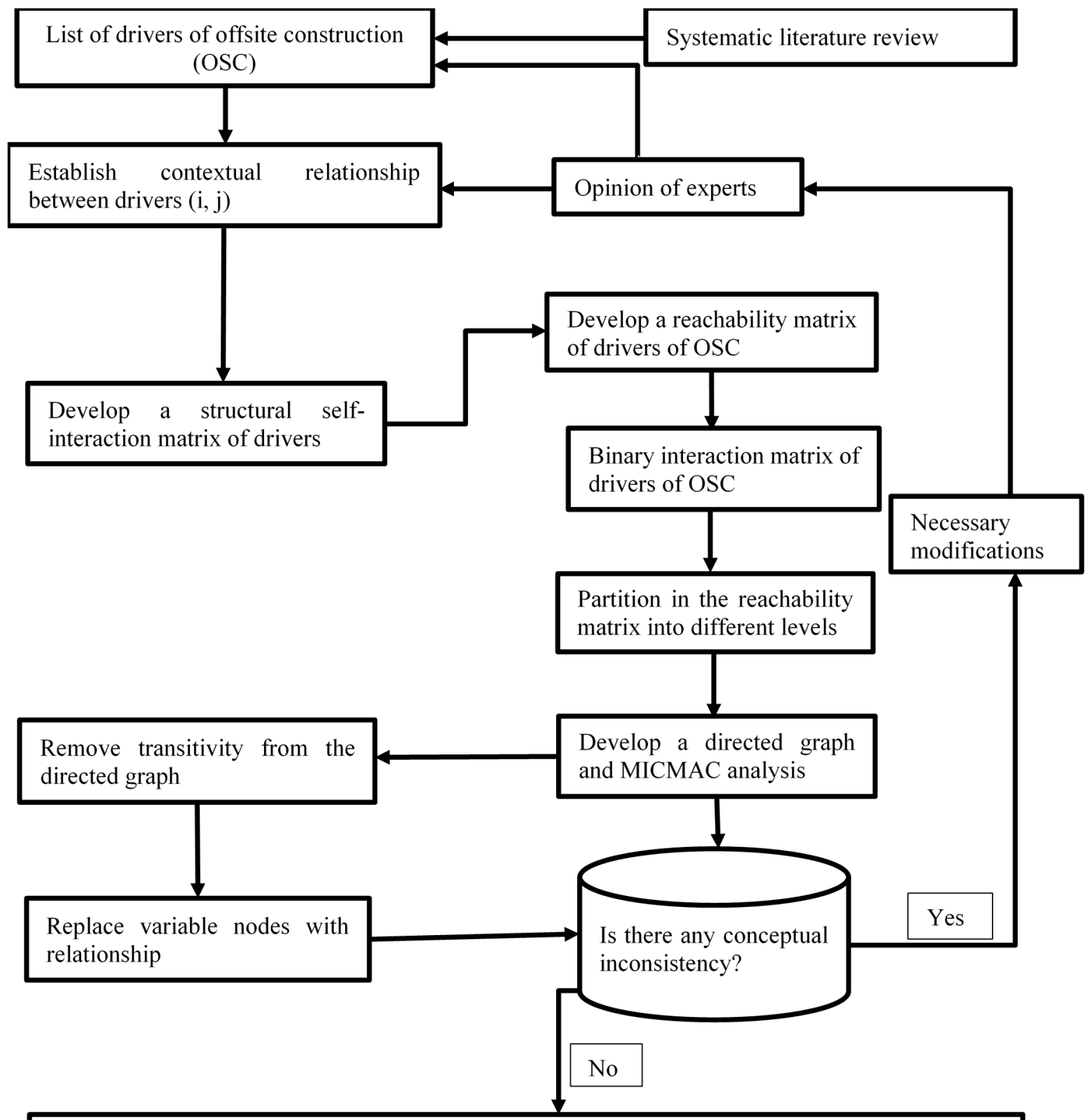

Total Interpretive Structural Model \& Conceptual Framework for Drivers of OSC

Figure 3. Total interpretive structural modelling procedure (adapted from [25]). 


\section{Review Findings and Discussions}

\subsection{Geospatial Distribution of the Included Studies on the Drivers of OSC}

Given the smaller sample size of the articles included in the study, it is useful to highlight their geospatial distribution as a justification of its representativeness in supporting a holistic analysis of the drivers of OSC. Figure 4 shows the geospatial distribution of the included articles across 10 countries located in Asia, North America, Australia, and Europe. These studies spanned between 2000 and 2019. Cohen et al. [38] demonstrated that public research has a significant positive impact on industrial innovation and development. Similarly, Hong et al. [39] noted that the research output of a country has a direct positive influence on its industrial and policy progress.

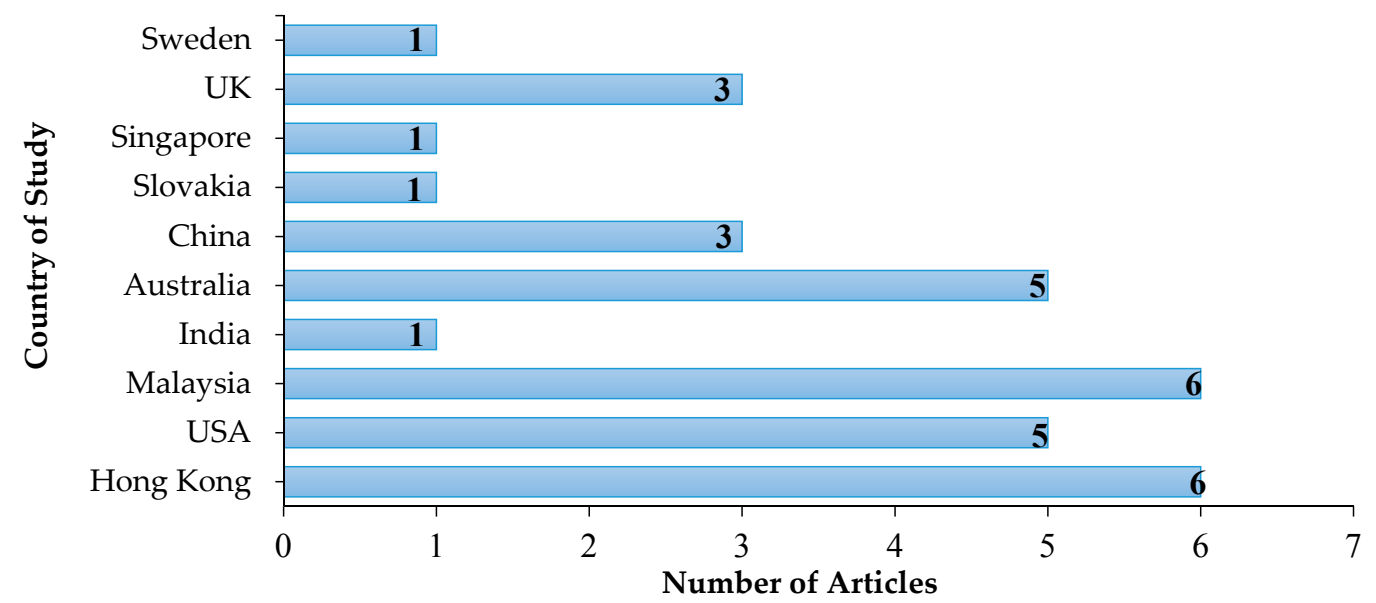

Figure 4. Geospatial distribution of research publications.

As such, countries with research publications on the drivers of OSC suggest that they are already promoting the approach and may offer useful research findings for countries yet to pursue the approach. Figure 4 shows that majority of the studies emanated from Hong Kong $(6,18.75 \%)$, Malaysia $(6,18.75 \%)$, USA $(5,15.63 \%)$, China $(3,9.38 \%)$, and the UK $(3,9.38 \%)$. These suggest that OSC researchers and practitioners in these countries are keen to understand the drivers of OSC as a basis for promoting the approach. Preponderances of the countries shown in Figure 4 constitute the frontline economies actively involved in the promotion of OSC and have established clear visions for the approach. OSC has national recognition in these countries for which roadmaps and incentives have been established to promote its adoption. For instance, in 2002, the Government of the Hong Kong Special Administrative Region (SAR) established the gross floor area concessions as an incentive scheme to encourage private developers to adopt prefabrications [40]. As part of the Policy Address 2017, the Hong Kong SAR Government announced its strong support and promotion of modular integrated construction (MiC) as a policy initiative to promote innovative construction towards the enhancement of construction productivity and to meet the need for high-density high-rise building construction [12]. The UK government established a policy stipulating that public housing development must incorporate $25 \%$ input of modern methods of construction, following the report entitled Rethinking Construction: Report of the Construction Task Force [41,42]. The Chinese government is also promoting OSC under the National New Urbanization Plan 2014-2020, which aims towards improving automation and productivity in the construction industry [43]. Similarly, the Construction Industry Development Board (CIDB) of Malaysia implemented the 2003-2010 and 2011-2015 IBS Roadmaps to promote OSC in the country [44]. Therefore, synthesizing the drivers of OSC as reported in these countries provide invaluable information to researchers, practitioners, and policymakers to champion the excellence of OSC. The countries shown in Figure 4 also comprise developing and developed economies. As such, the sample, albeit small, is deemed adequate for establishing a holistic perspective of the drivers of OSC. 


\subsection{Primary Actors and Stakeholders in Studies on the Drivers of OSC}

OSC stakeholders are individuals, groups, firms, companies, or institutions who can influence or be influenced by OSC projects and its uptake. OSC comes along with a unique composition of stakeholders and actors. Luo et al. [45] noted that OSC is associated with a complex web of stakeholders with unique goals and value systems within the OSC supply chain. Thus, it is useful to highlight the primary actors and stakeholders engaged in previous studies. This will offer a useful framework for the selection of respondents in future studies on OSC. Policymakers may also recognize the broader spectrum of stakeholders involved in the OSC revolutions. Figure 5 shows the stakeholders and actors who were dominantly engaged in studies involving the drivers of OSC. The figure shows a parade of giants and dwarfs of stakeholders and actors.

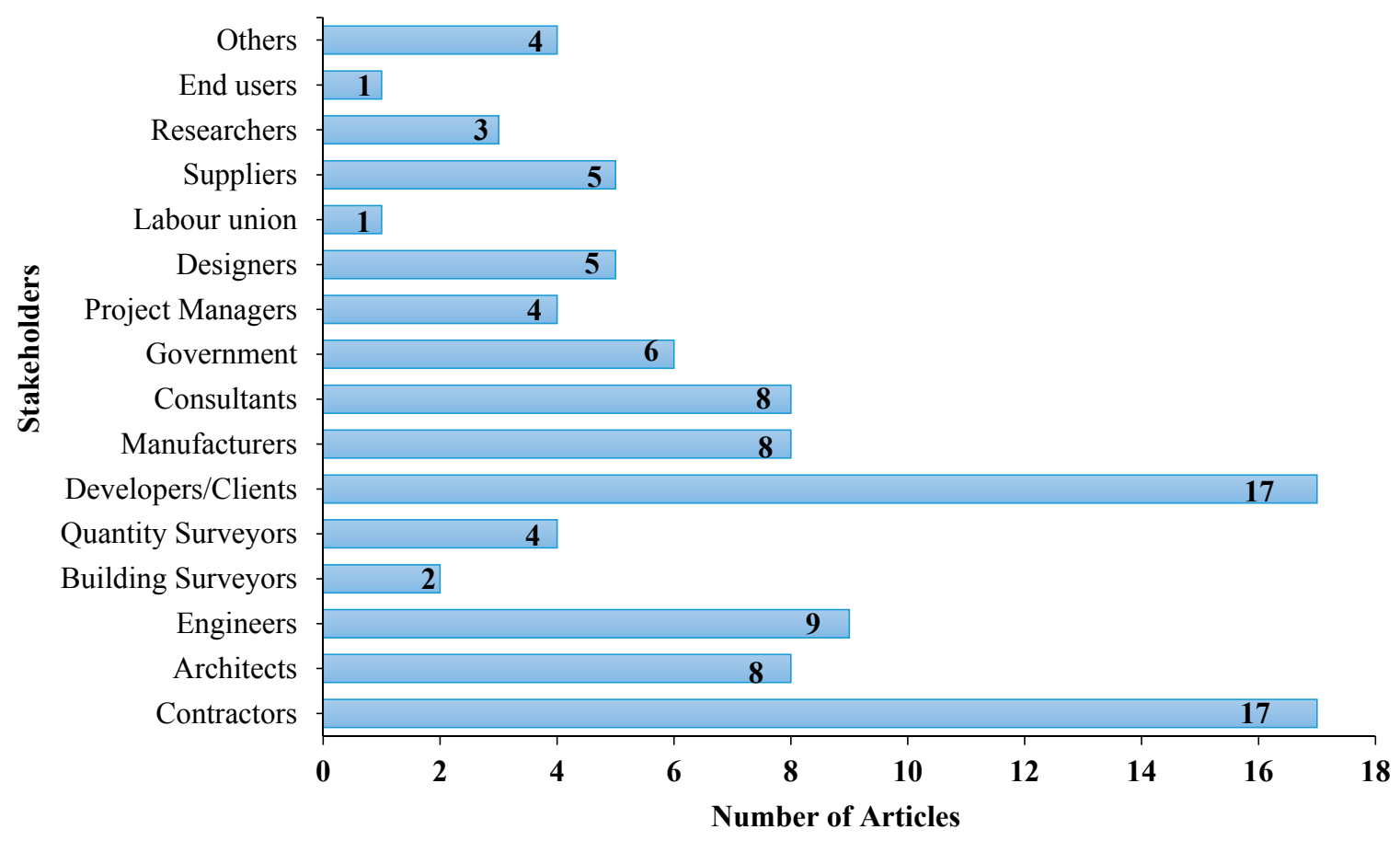

Figure 5. Primary stakeholders and actors in studies of the drivers of OSC.

The stakeholders shown in Figure 5 are the critical players in the OSC implementation trajectory and constitute the citizens of the OSC community with the greatest influence on the adoption of OSC [46]. The top six (6) most engaged OSC actors include contractors (17, 53.13\%), developers or clients $(17,53.13 \%)$, engineers $(9,28.13 \%)$, architects $(8,25 \%)$, consultants $(8,25 \%)$, and manufacturers $(8,25 \%)$. These multidisciplinary stakeholders and practitioners are the champions and leaders of construction innovation [47]. Therefore, previous studies on the drivers engaged the opinions of a diverse array of OSC stakeholders. Thus, the holistic perspective of the drivers of OSC in this study is a function of the aggregated opinions of these champions and leaders of construction innovation.

\subsection{Analysis of the Drivers of OSC}

The holistic review and synthesis of the past studies resulted in the extraction of 86 drivers of OSC. However, analysis of 86 unit drivers was considered too overwhelming and complex to Manag. As such, it is imperative to classify and cluster the drivers to offer a better understanding and facilitate the development of the conceptual framework. To support a comprehensive and in-depth analysis and modeling of the drivers, the study proposed an extended classification framework to cluster the drivers. The groupings of drivers of OSC in Blismas and Wakefield [10], Mao et al. [20], and Pan et al. [33] formed the basis for the current classification. Drawing on the adumbrated precedents, the 86 drivers of OSC were clustered into time performance (D1), cost performance (D2), quality performance 
(D3), productivity (D4), innovative competitiveness (D5), sustainability (D6), market (D7), and policy (D8) drivers. Tables 1-3 show the clusters of the drivers of OSC. These drivers are discussed in the following sections.

\subsubsection{Time Performance Drivers}

Amid increasing competition, construction companies are expected to be able to meet or exceed timelines to gain competitive an advantage. Similarly, housing authorities seek speedy delivery of homes to address the housing crisis [48]. In addition, time overrun and project delays remain a critical plague in the sector, with some large projects running $20 \%$ over time [5]. However, the traditional onsite construction approach is relatively inelastic to demand in the short-run. As such, the construction sector recognized the need for a technique which could offer speedy construction without compromising budgets and quality [41]. OSC is pursued in some countries for its chief benefit of speedy construction. Table 1 shows the time performance drivers of OSC. Time-saving has been reported as a critical driver of OSC [33,49]. OSC has proven to reduce construction time in the order of $30 \%$ to $70 \%$ [50]. The $30 \%$ to $70 \%$ reduced construction time translates into faster solvency for developers and cost-effectiveness for housing authorities. The shorter duration of OSC projects results in shorter payback periods and speedy returns on investment [51]. Experiences with OSC have proven that achievable time performance benefits include the decreased program time and certainty of project completion dates $[4,21,52]$. Choi et al. [53] reported that the transfer of major construction trades to the factory environment reduces the impact of weather disruptions on the timelines of OSC projects. The concurrent execution of multiple trades also decreases construction program time [4].

\subsubsection{Cost Performance Drivers}

The extent to which projects are completed within initial budgets measures the cost performance of the project. This may refer to construction cost or life cycle costs. Cost overrun constitutes a significant project management constraint in which preponderances of projects under the traditional cast-in-situ approach continue to exceed budgets [41]. Arcadis [6] found that construction industries in the major cities of the world continue to suffer cost escalation. According to McKinsey Global Institute [5], the majority of construction companies are not meeting budgets, with some large projects running up to $80 \%$ over budget. However, construction companies are expected to be able to meet or reduce budgets to gain the cost competitive advantage offered by competitors. OSC is pursued with the goal of simplifying the construction process towards reducing cost. The cost performance of OSC remains unclear since there are studies arguing that OSC increases cost $[54,55]$ and others demonstrating that OSC reduces construction cost [56].

Table 1. Time, cost, and quality drivers of OSC in empirical studies.

\begin{tabular}{ccc}
\hline Code & Drivers & References \\
\cline { 1 - 3 } D1 & Time Performance & \\
\hline 1 & Faster construction time & {$[4,16,21,23,44,51,52,57-62]$} \\
2 & Decreased program time & {$[4,21,52,57,59,61]$} \\
3 & Reduced payback period & {$[51,59]$} \\
4 & Reduction in lead-times & {$[15,51]$} \\
5 & Speedy return on investment & {$[51,59]$} \\
6 & Reduced design time & {$[24]$} \\
7 & Ensuring certainty of project completion time & {$[10,15,33,43,49,52]$} \\
8 & Improved schedule performance & {$[53]$} \\
9 & Reduced impact of weather disruptions & {$[44,53,63]$} \\
10 & Overall project timescale & {$[10,15,43]$} \\
\hline
\end{tabular}


Table 1. Cont.

\begin{tabular}{|c|c|c|}
\hline Code & Drivers & References \\
\hline D2 & Cost Performance & \\
\hline 1 & Reduction in construction costs & {$[10,16,21,22,51-53,57,58,64]$} \\
\hline 2 & Reduced labor demand and costs & {$[4,21,43,51,53,57,65,66]$} \\
\hline 3 & Maximization of returns & {$[21,57]$} \\
\hline 4 & Reduced whole lifecycle costs & {$[10,21,57,59]$} \\
\hline 5 & Reduced demolition and deconstruction costs & {$[23,51]$} \\
\hline 6 & Ensuring certainty of project costs & {$[10,15,33,43,49,52]$} \\
\hline D3 & Quality Performance & \\
\hline 1 & Achieving high quality projects & {$[4,10,33,43,44,49,52,53,58,60,66]$} \\
\hline 2 & Improved project quality control & {$[10,21,52,57,66]$} \\
\hline 3 & Improved quality of design and end-product & {$[21,57,65]$} \\
\hline 4 & Improved life cycle performance & {$[4,10,21,23,51,57,67]$} \\
\hline 5 & Improved the integrity of buildings & [22] \\
\hline 6 & Improved aesthetic performance & {$[22,68]$} \\
\hline 7 & Early design freeze & {$[22]$} \\
\hline 8 & Improved supervision & [22] \\
\hline 9 & Reduced snagging and defects & {$[4,52,66]$} \\
\hline 10 & Improved projects consistency & {$[10,52,66]$} \\
\hline 11 & Presence of repetitive layout in design & [15] \\
\hline 12 & Suitability of design for OSC & [15] \\
\hline
\end{tabular}

It is recognized that OSC is associated with a higher initial capital cost and longer breakeven period, resulting in little or no construction cost savings at the present in some cases [49]. It is further recognized that based on elemental cost parameters, such as labor, material, and transportation, OSC projects could be more expensive than conventional projects. However, when both soft and hard elements (e.g., improved safety, reduced time) are evaluated based on their value through the lens of cradle-to-grave analysis, OSC results in significant cost savings [4]. Table 1 shows some of the perceived cost drivers of OSC. Pan and Sidwell [56] compared two OSC techniques against two traditional ones in the UK and found that the former resulted in an $11 \%$ to $32 \%$ cost savings. Time savings is a necessary cost reduction driver, and considering the magnitude of time savings in OSC, the approach may result in cost-effectiveness in the sector following the optimization and benchmarking of best practices. Industry surveys found that the cost drivers of OSC include reduced labor requirement, the certainty of project cost, and reduced whole lifecycle cost $[10,33,51,52,56]$. Thus, this study argues that cost saving is an important driver of OSC.

\subsubsection{Quality Improvement Drivers}

The quality and standard of construction projects within the conventional construction approach are performing below satisfaction [41]. Egan [41] recommended the adoption of offsite production and client-led project delivery models to improve construction quality in the UK. Consistent with this recommendation, OSC is pursued in the UK and other countries to also improve construction quality. Table 1 shows the reported quality drivers of OSC in previous studies. The production of components in an offsite factory environment offers the opportunity for improved quality control [10]. Statutory and regulations demand that mock-ups and prototypes of each type of building component (module) in OSC are fabricated, checked, and tested before mass production. In most cases, trial assembly or stacking of modules in the factory is carried out before trucking to the site for final installation. This has generated high quality and high-profile exemplary OSC projects with improved lifecycle performance [10,33]. For projects with repetitive designs, such as prisons, student residences, residential estates, hotels, government buildings, and hospitals, OSC has a proven record of delivering projects with consistent 
quality and aesthetic performance $[15,17]$. Thus, this study argues that improvement in construction quality is a critical driver of OSC.

\subsubsection{Productivity Drivers}

The construction sector is identified as one of the least productive and efficient industries in the world. According to the McKinsey Global Institute [5], construction labor productivity recorded only a $1 \%$ annual increase in the last 20 years, far lower compared to that of manufacturing industries. Productivity improvement is now an unprecedented imperative in the construction sector. The need to improve the economic (value) and physical (schedule) productivity of the construction sector was recognized by the construction task force in the UK [41]. This lower productivity is arguably due to the linear fragmented site-based business model of the dominant construction technique, where one major stage needs to be completed before moving to the next stage. Pan and Hon [12] argued that one way to improve productivity in the sector is to transform the fragmented site-based construction of buildings to a value-driven driven production of buildings involving the assembly of prefinished volumetric building components. Similarly, McKinsey Global Institute [5] argued that a shift to an offsite production system involving mass production, standardization, prefabrication, and modularization has the potential to improve productivity in the construction sector. As OSC embraces the theories of modularity, modularization, value engineering, and lean production, it is pursued to improve construction productivity. Table 2 shows the reported productivity drivers of OSC. In the book entitled, Off-site Fabrication: Prefabrication, Pre-assembly and Modularization, Gibb [69] identified OSC as an innovative technology for improving construction productivity.

Table 2. Productivity, innovative competitiveness, and sustainability drivers of OSC.

\begin{tabular}{ccc}
\hline Code & Drivers & References \\
\hline D4 & Productivity Drivers & \\
\hline 1 & Improved site management and activities & {$[21,52,57,59]$} \\
2 & Need to improve construction productivity & {$[15,21,44,53,57,59,68]$} \\
3 & Lower project risk & {$[4,52,65]$} \\
4 & Increased component life & {$[10,60,66]$} \\
5 & Increased value for money & {$[4,52,60]$} \\
6 & Reduction in on-site activities & {$[4,33,44,49,52,66,68]$} \\
7 & Better site operations & {$[53,63]$} \\
8 & Better predictability and reliability & {$[53,66]$} \\
9 & Ease of applying lean principles & {$[70]$} \\
10 & Need to reduce reliance on manpower & {$[43]$} \\
D5 & Innovative Competitiveness Drivers & \\
\hline 1 & Ease of construction & {$[21,44,57,59]$} \\
2 & Partnership between companies & {$[21,57]$} \\
3 & Standardization opportunities & {$[21,23,57,65,67,68]$} \\
4 & Improved constructability and buildability & {$[23,51,65]$} \\
5 & Improved flexibility and adaptability & {$[23,51,65,68]$} \\
6 & Improved automation in construction & {$[24,67]$} \\
7 & Improved technology, such as BIM and RFID & {$[15,65]$} \\
8 & Technological innovation & {$[20]$} \\
9 & Increased competition from foreign firms & {$[16]$} \\
10 & Innovation and creativity pursuits & {$[68]$} \\
12 & Simplification of the construction process & {$[10,44,52,66]$} \\
\hline & Superior reputation & {$[20]$} \\
\hline
\end{tabular}


Table 2. Cont.

\begin{tabular}{ccc}
\hline Code & Drivers & References \\
\cline { 1 - 3 } D6 & Sustainability Drivers & \\
\cline { 1 - 3 } 1 & Reduction in construction dust & {$[21,57,58]$} \\
2 & Reduced noise in construction & {$[21,57,58,66]$} \\
3 & Improved health and safety of workers & {$[4,21,23,43,51-53,57,59,63]$} \\
4 & Improved working conditions and job security & {$[4,10,21,23,51,57,58]$} \\
5 & Lower footprint of construction materials & {$[21,51,57,59,66]$} \\
6 & Reduction in construction waste & {$[20,21,43,44,52,55,56,58,60,63$,} \\
7 & Decreased community disturbance & $66]$ \\
8 & Improving energy performance and efficiency & {$[23,51]$} \\
9 & Reducing construction water footprint & {$[10,44,51,66,71]$} \\
10 & Environmental concerns and requirements & {$[23,51,71]$} \\
11 & Reduced health and safety risk & {$[4,10,23,24,43,68,72]$} \\
12 & Reduced site disruptions & {$[4,10,15,33,49,60]$} \\
13 & Lower embodied carbon and emissions & {$[23,51,52,57,71,73]$} \\
14 & Pursuit of sustainable competitiveness & {$[4,23,33,49,51,52,57,71,73]$} \\
15 & Corporate social responsibility & {$[20,33,49]$} \\
16 & Need to meet sustainable targets & {$[20]$} \\
& & {$[20]$} \\
\hline
\end{tabular}

Table 3. Market and policy drivers of OSC in previous studies.

\begin{tabular}{ccc}
\hline Code & Drivers & References \\
\cline { 1 - 3 } D7 & Market Drivers & \\
\cline { 1 - 2 } 1 & Industry knowledge, experience and awareness & {$[15,65]$} \\
2 & Availability of expertise & {$[15,63,67,68]$} \\
3 & Improving client's satisfaction & {$[67]$} \\
4 & Addressing the industry skills shortage & {$[10,33,44,49]$} \\
5 & Availability of financial support & {$[58]$} \\
6 & Material and labor force shortages & {$[10]$} \\
7 & Client's demand for new technologies & {$[33,44,49]$} \\
8 & Construction market demand & {$[20]$} \\
9 & Stakeholders commitment & {$[68]$} \\
10 & Availability modular producers and suppliers & {$[68]$} \\
11 & Size and type or scope of projects & {$[15]$} \\
12 & Availability of OSC materials and equipment & {$[15,63]$} \\
\cline { 1 - 2 } D8 & Policy Drivers & \\
\cline { 1 - 2 } 1 & Incentive schemes and promotion & {$[23,33,49,67]$} \\
2 & Availability of trunk routes and highways & {$[15,63,65]$} \\
3 & Robust policy and legal framework & {$[20]$} \\
4 & Availability of adequate codes and guidance & {$[65]$} \\
5 & Revision of building code, regulation and permit & {$[20,33,44,49,63,65]$} \\
6 & Reduced site-based permits & {$[53]$} \\
7 & Government support, policies, and regulations & {$[20,43,68]$} \\
8 & Site location and layout & {$[15,63]$} \\
9 & Mandatory order and directive & {$[72]$} \\
\hline
\end{tabular}

Studies have demonstrated that the reduced onsite construction activities and improved site management in OSC are recipes for increased value for money [4,52,59]. OSC improves site operations, reduces labor demand, and provides a discrete chain for the application of lean production principles for continuous improvement $[43,53,70]$. Thus, the quest to improve productivity in the construction industry is a critical driver of OSC [20]. 


\subsubsection{Innovative Competitiveness Drivers}

Foreign construction firms continue to compete with local firms to build projects in most countries [16]. The competitive pressures compel firms to identify exceptional opportunities to meet or exceed timelines, minimize cost, and improve performance towards gaining a competitive advantage [20]. Table 2 shows the benefits of OSC in generating innovative competitiveness in the construction industry. According to Slaughter [74], OSC is an innovation because it engenders significant changes to some of the entrenched construction practices. OSC is a revolutionary disruptively-innovative constitution approach in the construction sector [12]. OSC is innovatively competitive because its primary goal is to simplify the construction process and create opportunities for standardization, automation, and mass production in the construction sector [75]. Mao et al. [20] concurred that the improved productivity and sustainability benefits of OSC strengthen the innovative and sustainable competitive advantage of construction firms. Industry surveys have shown that OSC is pursued to improve buildability, constructability, flexibility, and adaptability [76]. OSC improves construction engineering and facilitates effective delivery of difficult and complex projects under extreme weather and insecurity conditions $[23,51,77]$. Studies have also found that practitioners believe OSC provides an improved platform for the integration of technologies, such as building information modeling (BIM) and radio frequency identification (RFID), into the construction process, which enhances better predictability, assessment, and monitoring of building construction projects $[15,20,65]$.

\subsubsection{Sustainability Drivers}

As one of the seven most violent contributors to climate change [1], the construction sector is required to contribute to the sustainable development goals (SDGs). Aside from the green building movement, OSC is one approach towards improving the sustainability of the built environment and the construction sector [51,57]. OSC is pursued in some countries to enhance the sustainability of the sector. It should be indicated that sustainability is very obscure to delineate exhaustive boundaries and thus, several components of the other clusters of drivers could be well-placed under the sustainability drivers of OSC. Nonetheless, Table 2 shows the sustainability benefits of OSC. Several studies have been conducted to verify the improved sustainability benefits of OSC over the traditional cast-in-situ construction approach. In an industry survey in the UK, McGraw Hill Construction [78] found that the majority of general and specialty contractors believed OSC improved the health and safety of construction workers, resulting from the controlled factory condition, fewer onsite construction activities, reduced number of workers on site, and the reduced requirement to work from heights. In Hong Kong, Tam et al. [22] found prefabrication could achieve a $100 \%$ construction waste reduction and $84 \%$ wastage reduction. Similarly, Jaillon and Poon [57] found that prefabrication results in a $41 \%$ reduction in the construction water footprint. Quale et al. [73] found that modular homes have a lower lifecycle environmental impact compared to traditional homes. Mao et al. [71] found that OSC results in lower embodied carbon and emissions $\left(336 \mathrm{~kg} / \mathrm{m}^{2}\right)$ compared to the traditional construction approach $\left(368 \mathrm{~kg} / \mathrm{m}^{2}\right)$. Pan and Sidwell [56] proved that OSC results in an $11 \%$ to $32 \%$ cost savings over the traditional construction technique. Some practitioners also noted that OSC reduces community disturbance, site disruptions, dust, and materials wastage $[10,49,51,57]$. Thus, the adoption of OSC may constitute a significant milestone in the construction sector towards contributing to the sustainable development goals [20].

\subsubsection{Construction Market Drivers}

The rapid wave of population growth and urbanization in the world comes along with a concomitant rise in the demand for infrastructure and built environment services [43,48]. The existing demand pressure on the construction sector is overwhelming and overpowering the responsive capability of the traditional construction approach. As such, cost-effective and time-driven construction techniques are now an unprecedented imperative for the sector. Also, expansion of the green building 
market towards reducing the carbon footprint of the sector is generating motivations and an impetus for leveraging innovative construction technologies. In response, OSC is becoming a critical aspect of the business models and organizational strategies of high-profile construction companies, such as China State Construction Engineering Corporation, China Railway Group Limited, China Railway Construction Corporation, Vinci SA, and Grupo ACS. Table 3 shows the reported construction market drivers of OSC. OSC is pursued to improve the satisfaction of construction clients [65,69], to meet housing and infrastructure demand [48], and to address the surging skills shortage owing to the rapid aging and shrinking of the construction workforce [4]. These visions seem feasible when analyzed in tandem with the increasing availability of OSC industry expertise, manufacturers, suppliers, and production materials. The OSC market climate looks promising considering that some clients increasingly demand the use of OSC techniques to deliver their projects [23]. Similarly, the shorter schedules and scope of construction projects in densely populated cities, such as Hong Kong, constitute unique market forces compelling the adoption of OSC $[15,20,63]$.

\subsubsection{Policy Drivers}

Based on the opinions of 83 developers in China, Mao et al. [79] found the "absence of government regulations and incentives" was perceived as the most critical barrier to the adoption of OSC. The existence of robust OSC policies and legal frameworks constitute policy drivers of OSC. OSC policies highlight the commitment of policymakers toward promoting the approach. As expected, the government is the greatest stakeholder and actor in the OSC revolution in the UK, Hong Kong, Malaysia, and in many other countries. As such, there are government support, policies, regulations, incentives, and promotion schemes to encourage the adoption of OSC.

A significant policy driver is the revision of building codes, regulations, and permits to encourage the adoption of OSC $[44,49,65]$. Table 3 shows the reported policy drivers of OSC in previous studies. There are several policy initiatives that recognize and promote the adoption of OSC in many countries. The National Research Council of the United States stipulated officially that the wider use of PPMOF—-prefabrication, preassembly, modularization, and off-site fabrication -is one significant breakthrough needed in the construction sector within the next two decades in the report "Advancing the Competitiveness and Efficiency of the US Construction Industry". The Swedish government is championing the use of OSC to streamline the delivery and building of 250,000 modern and flexible modular homes in response to the growing housing crisis [12]. In 2004, the Cooperative Research Centre for Construction in Australia launched the initiative "Construction 2020" to promote the use of OSC in the country. The New Zealand government is currently promoting the use of OSC to deliver modular social housing. The Korean government invested \$30 million in OSC research and development with the aim of engineering advanced modular methods to support commercial and residential construction. In 2016, the Chinese government initiated an OSC policy demanding that prefabricated building must constitute $30 \%$ of all new construction in the next decade [12,43]. Similarly, the Building and Construction Authority (BCA) of Singapore is promoting the adoption of prefabricated prefinished volumetric construction (PPVC) under the Code of Practice on Buildability 2015 to enhance construction productivity in the country [15]. These suggest that there are diversified policies, practice priorities, and foci in the promotion of OSC. However, they highlight the policy drivers of OSC and thus, this study argues that policy is a critical driver of OSC.

\subsection{TISM Modeling and Conceptual Framework for the Drivers of OSC}

\subsubsection{Structural Self-Interaction Matrix (SSIM) of the Drivers of OSC}

The first modeling step in the TISM approach is to develop the structural self-interaction matrix of the problem or system [25]. This involves listing all the critical variables (drivers) and establishing their contextual relationships based on the consensual opinions of domain experts. However, the authors conducted brainstorming sessions and plenary discussions to establish these relationships. The authors 
first developed a paired matrix of the eight clusters of drivers (Table 4) and cross-examined them to identify how each driver influences or is influenced by another driver. Differences in opinions were easily resolved by seeking justifications from each author and establishing a consensus. Drawing on Sushil $[25,26]$, the interactions of the drivers of OSC were denoted using the letters $\mathrm{V}, \mathrm{A}, \mathrm{X}$, and O. The columns and rows of the paired matrix are denoted by $i$ and $j$.

Table 4. Structural self-interaction matrix (SSIM) of the drivers of OSC.

\begin{tabular}{ccccccccc}
\hline & D8 & D7 & D6 & D5 & D4 & D3 & D2 & D1 \\
\hline D1 & O & V & O & O & X & A & V & X \\
D2 & A & V & V & A & X & A & X & \\
D3 & A & A & V & A & X & X & & \\
D4 & V & V & A & A & X & & & \\
D5 & O & A & V & X & & & & \\
D6 & A & V & X & & & & & \\
D7 & X & X & & & & & & \\
D8 & X & & & & & & &
\end{tabular}

Notes: D1 = time performance; D2 = cost performance; D3 = quality performance; D4 = productivity performance; D5 = innovative competitiveness; D6 = sustainability; D7 = construction market; and D8 = policy drivers.

The letters in Table 4 are interpreted as $\mathrm{V}$-means driver " $\mathrm{i}$ " influences or enhances driver " $\mathrm{j}$ " and " $\mathrm{j}$ " does not influence " $\mathrm{i}$ "; $\mathrm{A}-$ means driver " $\mathrm{i}$ " does not enhance driver " $\mathrm{j}$ ", but " $\mathrm{j}$ " leads to driver " $\mathrm{i}$ "; $\mathrm{X}$-means driver " $\mathrm{i}$ " influences driver " $\mathrm{j}$ " and " $\mathrm{j}$ " also leads to " $\mathrm{i}$ "; and $\mathrm{O}-$ means driver " $\mathrm{i}$ " and driver " $j$ " have no links. For each of the pairs ( $i, j)$ of the drivers in Table 4 , the authors used brainstorming and discussion sessions to identify their interactions based on yes $(\mathrm{Y})$ or no $(\mathrm{N})$ responses. The checklist of drivers in Table 1 to Table 3 facilitated the establishment of the interactions of the drivers. For each $Y$, the authors identified the nature of the relationships based on the checklists. A compilation of all the consensual interactions constituted the Interpretive Logic-Knowledge Base [25] and was used in determining the transitive links among the drivers of OSC.

\subsubsection{Reachability Matrix (Initial and Final) of the Drivers of OSC}

The next step in the TISM approach is to convert the SSIM to an initial reachability matrix (RM) of the drivers. Using the Interpretive Logic-Knowledge Base for the paired comparisons of all the drivers, it was quite easy to establish the initial RM. Drawing on Sushil $[25,26]$, the authors replaced each $Y$ by 1 and each $\mathrm{N}$ by 0 . Particularly, for each: (a) V entry, 1 was recorded for $(i, j)$ and 0 for each $(j, i)$; (b) A entry in the SSIM, 0 was entered for $(i, j)$ and 1 for $(j, i)$; (c) X entry, 1 was entered for both $(i, j)$ and ( $j, i)$; and (iv) $O$ entry, 0 was entered for both (i, j) and (j, i). The authors then converted the initial RM to final RM (Table 5) based on the transitivity property [80].

Table 5. Final reachability matrix of drivers of OSC.

\begin{tabular}{ccccccccc}
\hline & D1 & D2 & D3 & D4 & D5 & D6 & D7 & D8 \\
\hline D1 & 1 & 1 & 1 & 1 & 0 & 0 & 1 & 0 \\
D2 & 0 & 1 & 0 & 1 & 0 & 1 & 1 & 0 \\
D3 & 1 & 1 & 1 & 0 & 0 & 1 & 0 & 0 \\
D4 & 1 & 1 & 0 & 1 & 0 & 0 & 1 & 1 \\
D5 & 1 & $1^{*}$ & $1^{*}$ & 1 & 1 & 1 & $1^{*}$ & 1 \\
D6 & $1^{*}$ & 1 & 1 & 1 & 1 & 1 & $1^{*}$ & $1^{*}$ \\
D7 & 0 & 0 & 1 & 0 & 1 & 0 & 1 & 1 \\
D8 & 0 & 0 & 1 & 0 & 1 & 0 & 1 & 1 \\
\hline
\end{tabular}

Note*: indicates checked for transitivity relation. 
Transitivity relation dictates that for binary operation, if driver " $a$ " influences driver " $b$ " and driver " $b$ " enhances driver " $c$ ", then driver "a" also influences driver " $c$ ". The use of the transitivity property in TISM maintains consistency in the model [80].

\subsubsection{Binary Interaction Matrix (BiM) of the Drivers of OSC}

The final RM was then converted to a binary interaction matrix (Table 6) of the drivers of OSC. Reference was constantly made to the Interpretive Logic-Knowledge Base to ensure consistency. The BiM of the drivers is a direct replica of the final RM, but includes the computed values for the driving power and dependences of the drivers. The total dependences of the drivers are computed as the vertical summation of the transitive links whereas the driving powers are computed as the horizontal summation of the transitive links.

Table 6. Binary interaction matrix of the drivers of OSC.

\begin{tabular}{cccccccccc}
\hline & D1 & D2 & D3 & D4 & D5 & D6 & D7 & D8 & Driving Power \\
\hline D1 & 1 & 1 & 1 & 1 & 0 & 0 & 1 & 0 & 5 \\
D2 & 0 & 1 & 1 & 1 & 0 & 1 & 1 & 0 & 5 \\
D3 & 1 & 1 & 1 & 0 & 0 & 1 & 0 & 0 & 4 \\
D4 & 1 & 1 & 0 & 1 & 0 & 0 & 1 & 1 & 5 \\
D5 & 1 & 1 & 1 & 1 & 1 & 1 & 1 & 1 & 8 \\
D6 & 1 & 1 & 1 & 1 & 1 & 1 & 1 & 1 & 8 \\
D7 & 0 & 0 & 1 & 0 & 1 & 0 & 1 & 1 & 4 \\
D8 & 0 & 0 & 1 & 0 & 1 & 0 & 1 & 1 & 4 \\
Dependence & 5 & 6 & 7 & 5 & 4 & 4 & 8 & 5 & \\
\hline
\end{tabular}

\subsubsection{Level (Hierarchical) Partitions in the Reachability Matrix of the Drivers of OSC}

Based on the principles of ISM [34] and TISM [25], the reachability set and antecedent sets were computed to ascertain the hierarchies of the drivers of OSC. Computation of the level matrix is an iterative process [25]. The hierarchical levels were derived by ranking the different drivers (clusters) and partitioning their positions in the model. However, like Gahana et al. [27], the study used the computed values of the total dependences and driving powers to identify the levels (Table 7) of the drivers in the final RM.

Table 7. Level matrix of the drivers of OSC.

\begin{tabular}{cc}
\hline Drivers & Hierarchies \\
\hline D3, D7, D8 & Level 1 \\
D1, D2, D4 & Level 2 \\
D5, D6 & Level 3 \\
\hline
\end{tabular}

The highest-level variables are the drivers in the iteration where the reachability sets an intersection with the antecedent set is a reachability set itself $[25,27]$. Table 7 shows the results of the iterative levels partitioning in the final RM.

\subsubsection{Directed Graph and MICMAC Analysis of the Drivers of OSC}

Based on the hierarchical levels of the drivers in Table 7, the study developed a directed graph. A directed graph is a graph showing a set of vertices or nodes of the drivers that are connected, where all the edges are directed from one vertex to another. This was facilitated through a cross-impact matrix multiplication applied to classification (MICMAC) analysis of the drivers, as shown in Table 6. Warfield [34] pioneered the use of MICMAC analysis to examine the hierarchical interactions of variables based on driving powers and dependences. In the TISM approach, MICMAC analysis was used to 
cluster the drivers into four categories comprising dependence, linkage, driving, and autonomous variables (drivers). Figure 6 shows a directed graph of the drivers of OSC.

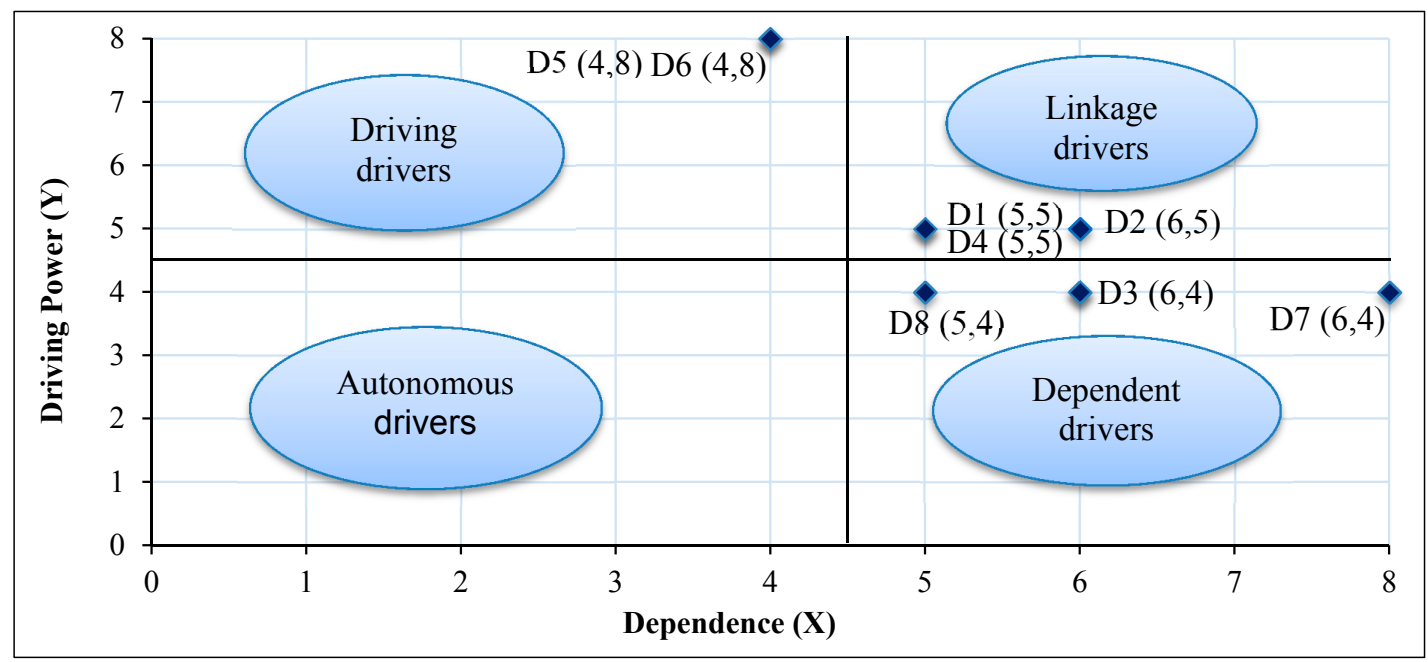

Figure 6. Directed graph and MICMAC analysis of the drivers of OSC.

The dependent drivers are associated with weak driving power and higher dependences. The second cluster is the linkage drivers, followed by the independent variables, and finally, the autonomous drivers, associated with the least driving power and dependences.

\subsection{Discussion of the TISM Model of the Drivers of OSC}

Drawing on the Interpretive Logic-Knowledge Base, the final RM, binary matrix, and the directed graph, the authors developed the transitive links among the drivers of OSC. The transitive links (Table 8) demarcates the drivers and explains how they precisely interact within the TISM model (Figure 7). It is found that the drivers are complex, numerous, and interactive. Through the lens of graph theory and systems-thinking, the TISM model (Figure 7) is a holistic conceptual framework of the drivers of OSC, mapping their intrinsic and extrinsic structure and interactions. The comprehensive conceptual framework explores the ecosystem of eight (8) clusters of drivers, comprising time performance (D1), cost performance (D2), quality performance (D3), productivity pursuit (D4), innovative competitiveness (D5), sustainability (D6), construction market evolution (D7), and policy (D8) drivers.

To ensure the validity and correctness of the framework, the initial model was checked against the TISM validity principles outlined in Sushil [26]. The authors also checked for any conceptual inconsistencies in the framework and made the necessary corrections based on the Interpretive Logic-Knowledge Base. Based on the relative importance and hierarchies of the drivers in the directed graph and MICMAC analysis (Figure 6), the TISM model shows that the pursuit of innovative competitiveness (D5) and sustainability (D6) are the two most important drivers with the highest driving power and lowest dependences. From Figure 7, D5 and D6 persuade the adoption of OSC through improved time performance (D1), cost performance (D2), and productivity (D4); which constitute linkage drivers in the TISM model. Although D5 and D6 are both situated within the third level of the TISM model, their strong driving power allows them to influence and enhance the other drivers within the model. Quality drivers (D3), construction market drivers (D7), and policy drivers (D8) are all located in the first level, suggesting that they have a significant influence on the adoption of OSC, but depends so much on the success of the second and third level drivers. 
Table 8. Transitive links of the drivers of OSC based on the Interpretive Logic-Knowledge Base.

\begin{tabular}{|c|c|c|c|c|c|c|c|c|}
\hline & D1 & D2 & D3 & D4 & D5 & D6 & D7 & D8 \\
\hline D1 & & $\begin{array}{c}\text { Faster } \\
\text { construction time }\end{array}$ & $\begin{array}{c}\text { Reduced } \\
\text { design time }\end{array}$ & $\begin{array}{l}\text { Improved } \\
\text { schedule } \\
\text { performance }\end{array}$ & & & $\begin{array}{l}\text { Overall project } \\
\text { timescale }\end{array}$ & $\begin{array}{l}\text { Speedy and } \\
\text { affordable } \\
\text { housing }\end{array}$ \\
\hline D2 & & & & $\begin{array}{c}\text { Reduced labor } \\
\text { demand and cost }\end{array}$ & & $\begin{array}{l}\text { Reduced whole } \\
\text { lifecycle costs }\end{array}$ & $\begin{array}{c}\text { Ensuring certainty } \\
\text { of project costs }\end{array}$ & \\
\hline D3 & $\begin{array}{l}\text { Early design } \\
\text { freeze }\end{array}$ & $\begin{array}{l}\text { Achieving } \\
\text { high-quality } \\
\text { projects }\end{array}$ & & & & $\begin{array}{c}\text { Improving } \\
\text { lifecycle } \\
\text { performance }\end{array}$ & & \\
\hline D4 & $\begin{array}{l}\text { Reduction in } \\
\text { on-site activities }\end{array}$ & $\begin{array}{c}\text { Improved site } \\
\text { management } \\
\text { and activities }\end{array}$ & & & & & $\begin{array}{l}\text { Increased value } \\
\text { for money }\end{array}$ & $\begin{array}{l}\text { Need to reduce } \\
\text { reliance on } \\
\text { manpower }\end{array}$ \\
\hline D5 & $\begin{array}{l}\text { automation in } \\
\text { construction }\end{array}$ & $\begin{array}{l}\text { automation in } \\
\text { construction }\end{array}$ & $\begin{array}{l}\text { Improved } \\
\text { flexibility }\end{array}$ & $\begin{array}{l}\text { automation in } \\
\text { construction }\end{array}$ & & $\begin{array}{c}\text { Improving } \\
\text { satisfaction } \\
\text { of clients }\end{array}$ & $\begin{array}{l}\text { Competition from } \\
\text { foreign firms }\end{array}$ & $\begin{array}{c}\text { Standardization } \\
\text { opportunities }\end{array}$ \\
\hline D6 & $\begin{array}{l}\text { Reduced site } \\
\text { disruptions }\end{array}$ & $\begin{array}{c}\text { Reducing } \\
\text { construction } \\
\text { water footprint }\end{array}$ & $\begin{array}{l}\text { Need to meet } \\
\text { sustainable } \\
\text { targets }\end{array}$ & $\begin{array}{c}\text { Reduction in } \\
\text { construction } \\
\text { waste }\end{array}$ & $\begin{array}{c}\text { The pursuit of } \\
\text { sustainable } \\
\text { competitive } \\
\text { advantage }\end{array}$ & & $\begin{array}{l}\text { Corporate social } \\
\text { responsibility }\end{array}$ & $\begin{array}{c}\text { Lower } \\
\text { embodied } \\
\text { carbon and } \\
\text { emissions }\end{array}$ \\
\hline D7 & & & $\begin{array}{l}\text { Availability of } \\
\text { expertise }\end{array}$ & & Scope of projects & & & $\begin{array}{l}\text { Addressing the } \\
\text { industry } \\
\text { skills shortage }\end{array}$ \\
\hline D8 & & & $\begin{array}{l}\text { Adequate codes } \\
\text { and guidance }\end{array}$ & & $\begin{array}{l}\text { Government } \\
\text { policies and } \\
\text { regulations }\end{array}$ & & $\begin{array}{l}\text { Incentive schemes } \\
\text { and promotion }\end{array}$ & \\
\hline
\end{tabular}




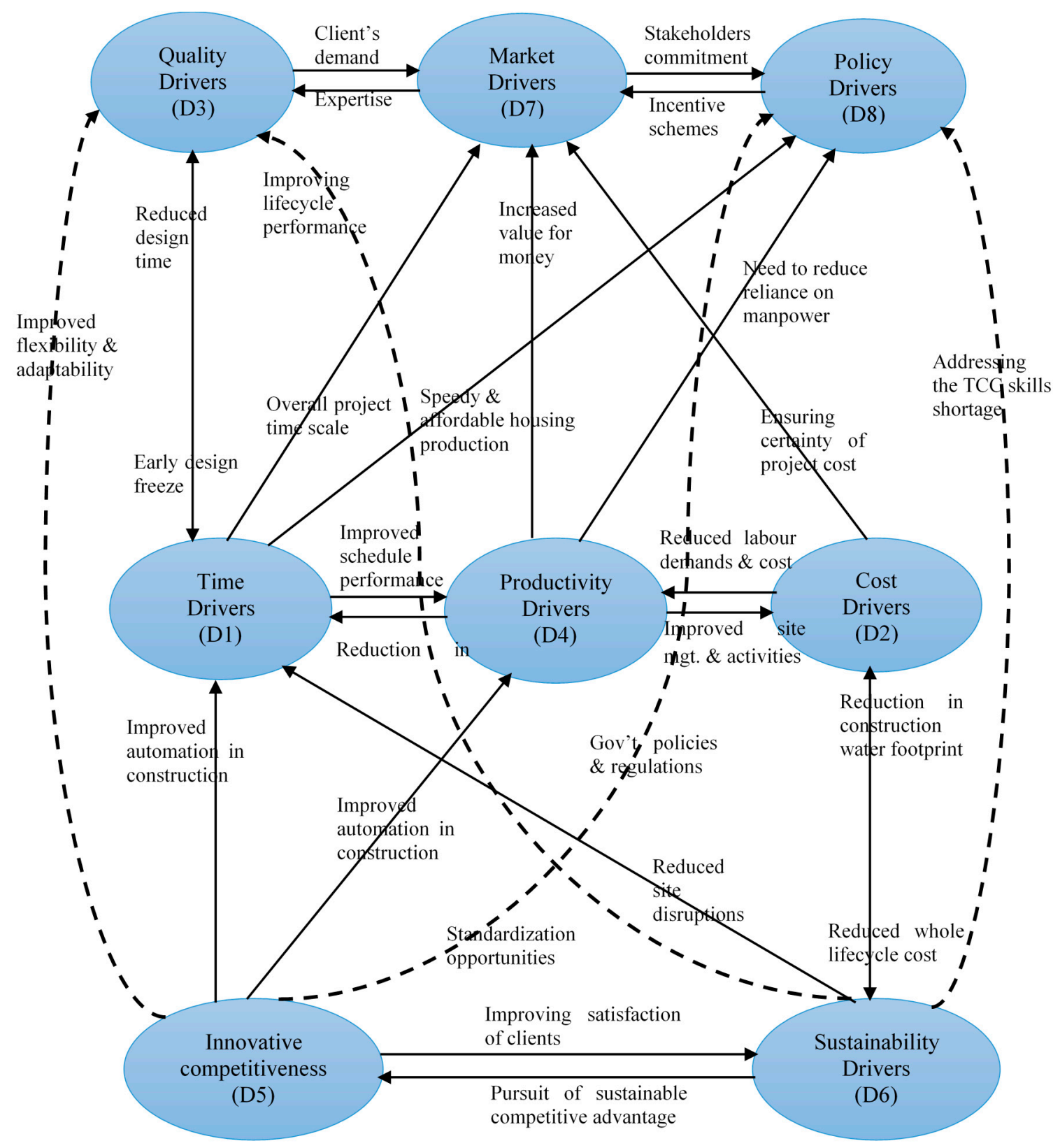

Figure 7. TISM model of the drivers of offsite construction (OSC).

From Figure 7, the pursuit of sustainability (D6) targets partly drives the commitment to be innovatively competitive (D5) to gain a sustainable competitive advantage. Due to the triple bottom line, the sustainability (D6) benefits also include cost savings (D2) due to the lower lifecycle cost and improved productivity (D4) owed to reduced construction waste and onsite labor demand. Additionally, the pursuit of innovative competitiveness (D5) results in improved automation in construction; which is a necessary driver of time (D1), cost (D2), and improved productivity (D4). Time performance (D1), cost performance (D2), and improved productivity (D4) are known as the linkage drivers with relatively strong driving power and dependences. Thus, conflicts within and among these drivers would greatly affect the interactions between the first and third level drivers. Essentially, the effective management of the driving (third level) and the linkage (second level) drivers could significantly improve quality performance (D5), construction market (D7) demand, and policy (D8) support. Moreover, from Figure 7, the quest to reduce reliance on manpower is receiving policy attention towards improving productivity (D4) in the construction industry [5,12,43]. Additionally, improved cost performance due to the 
certainty of project cost enhances the perception in the construction market that OSC could be a panacea to the cost overrun syndrome in the sector. The increased value for money associated with improved productivity encourages wider market acceptance of OSC [4]. Finally, the position of D3, D7, and D8 highlight their sensitivity and absolute dependence on the performances of the other drivers. Thus, policymakers may prioritize the second and third level drivers in any intervention since they could breed and enhance some of the first level drivers.

\section{Theoretical and Practical Contributions of the Study}

The study draws heavily on Whetten's [81] seminal work on "What Constitutes a Theoretical Contribution?" to justify the theoretical and practical contribution of this study. Theoretically, the study makes the following contributions. Firstly, the study has provided a holistic review and perspective of the drivers of OSC. It generated a balance between the comprehensiveness and parsimony of the 86 drivers of OSC in previous studies. The study achieved this by developing an extended classification framework to group the 86 drivers into eight clusters, allowing for a better understanding. Secondly, the study proposed a self-explanatory conceptual framework for the drivers of OSC. The TISM model represents a unique extension of the works of Blismas and Wakefield [10] and Mao et al. [20] by exploring the holistic interactions and ecosystem of the drivers of OSC based on driving powers and dependences. Thirdly, the study constitutes a part of the very few studies which have successfully deployed the TISM approach to build a conceptual framework in the CEM research domain. This is unique because the TISM model has revealed what constitutes the drivers, how they interact, and why such interactions prevail. Fourthly, the proposed extended classification framework of the drivers contributes to the checklist of drivers in the OSC literature and may form the basis for conducting a rigorous further empirical analysis of the hypothetical links among the drivers.

The research has the following practical implications. Firstly, the holistic review and TISM modeling of the drivers brings the empirical literature closer to managerial and policy decision-making as a broader perspective has been provided. Secondly, through the TISM approach, the critical clusters of drivers and their hierarchical levels have been identified based on driving powers and dependences. This would inform decision-making at the policy and managerial level on the drivers to prioritize in the development of an integrated intervention mechanism to achieve wider adoption of OSC. Effectively, this may guide the development of a managerial framework to determine the strategic allocation of resources with the potential to contribute to a wider uptake of OSC. Finally, the highlighted critical drivers may constitute the basis for implementing the Aristotelian rhetoric strategies, such as ethos, pathos, and logos, in diffusing OSC into the construction sector.

\section{Conclusions, Limitations, and Future Research}

Although the construction sector is conservative and sluggish in the adoption of innovation, one overt transition is the growing paradigm shift towards OSC. Different countries and companies are pursuing OSC for various reasons. Amid the diversified OSC policies, practice priorities, and foci, there is a growing body of literature examining the drivers and benefits of OSC. This research conducted a holistic review and proposed a conceptual framework for the drivers of OSC using the total interpretive structural modelling (TISM) approach. The paper adopted a multistage methodological approach comprising a systematic literature review, plenary discussion, and building of a conceptual framework. Based on a content analysis framework, the systematic literature review generated 86 drivers of OSC. To improve understanding, the study proposed an extended classification framework to group the 86 drivers into time (D1), cost (D2), quality (D3), productivity (D4), innovative competitiveness (D5), sustainability (D6), market (D7), and policy (D8) clusters of drivers. These formed the basis for the TISM model of the drivers. A MICMAC analysis did not reveal any autonomous drivers, suggesting that all the clusters of drivers are significant in the adoption of OSC. The TISM model revealed that the pursuit of innovative competitiveness (D5) and sustainability (D6) are the two most important drivers with the highest driving power and lowest dependences. They were placed in the bottom 
(third level) of the TISM hierarchy, highlighting that they significantly influence and enhance the rest of the drivers and should be prioritized in policy intervention. The MICMAC analysis generated time (D1), cost (D2), and productivity (D4) as the linkage drivers with relatively strong driving power and dependence. This instructs that conflicts among them should be minimized as they mediate the interactions between the first and third level drivers. The MICMAC analysis also generated quality (D3), market (D7), and policy (D8) as first level drivers in the TISM model, highlighting their sensitivity and absolute dependence on the performance of the second and third level drivers. These findings have useful theoretical and practical implications as documented in Section 4.

However, the results should be interpreted against the following limitations. Firstly, the authors immediately recognize that the sweeping generalization of the drivers and their interactions overlook their geospatial sensitivity. Nonetheless, the authors argue that it is often theoretically useful to overlook these geospatial sensitivities and differences since they become absolutely critical when such generalized analysis is tailored towards a specific country as a basis for policy recommendation. Secondly, the generalization in the TISM framework may not be adequate because of the absence of empirical data. As such, future studies will examine and compare the holistic interactions of the drivers in different countries using empirical data. Future studies will also explore the interlinkages of the drivers using fuzzy MICMAC analysis to include a sensitivity assessment of the model.

Author Contributions: Conceptualization, I.Y.W.; Methodology and Literature Retrieval I.Y.W.; Writing, Original Draft Preparation, I.Y.W.; Writing, Review, and Editing, G.Q.P.S.; Supervision, G.Q.P.S.

Funding: This research was fully funded by the Department of Building and Real Estate of the Hong Kong Polytechnic University under the Hong Kong Ph.D. Fellowship Scheme (PF17-00649).

Acknowledgments: The authors wish to acknowledge the Department of Building and Real Estate of the Hong Kong Polytechnic University for funding the study. The authors also acknowledge the anonymous reviewers whose comments have helped in improving the quality of the paper.

Conflicts of Interest: The authors declare no conflict of interest.

\section{References}

1. Intergovernmental Panel on Climate Change. Climate Change 2007 Synthesis Report, 2007. Available online: http://streitcouncil.org/uploads/PDF/Report-Climate\%20Change\%202007-\%20Impacts, \%20Adaptation,\%20and\%20Vulnerability.pdf (accessed on 15 April 2019).

2. Seadon, J.K. Sustainable waste management systems. J. Cleaner Prod. 2010, 18, 1639-1651. [CrossRef]

3. Ajayi, S.O.; Oyedele, L.O.; Bilal, M.; Akinade, O.O.; Alaka, H.A.; Owolabi, H.A.; Kadiri, K.O. Waste effectiveness of the construction industry: Understanding the impediments and requisites for improvements. Resour. Conserv. Recycl. 2015, 102, 101-112. [CrossRef]

4. Blismas, N.; Pasquire, C.; Gibb, A. Benefit evaluation for off-site production in construction. Constr. Manag. Econ. 2006, 24, 121-130. [CrossRef]

5. McKinsey Global Institute, Reinventing Construction: A Route to Higher Productivity, New York, United States, 2017. Available online: https:/www.mckinsey.com/ \{\}/media/McKinsey/Industries/Capital\% 20Projects\%20and\%20Infrastructure/Our\%20Insights/Reinventing\%20construction\%20through\%20a\% 20productivity\%20revolution/MGI-Reinventing-construction-A-route-to-higher-productivity-Full-report. ashx (accessed on 15 April 2019).

6. Arcadis. Tackling Costs in the Digital Age: International Construction Costs 2018, Amsterdam, Netherlands, 2018. Available online: https://www.arcadis.com/media/F/1/E/\%7BF1E33F46-EA9C-4F75A642-E0E0F31420BD\%7DInternational-Construction-Costs-2018-Arcadis-Updated_001.pdf (accessed on 14 April 2019).

7. Lu, N.; Liska, R.W. Designers' and general contractors' perceptions of offsite construction techniques in the United State construction industry. Int. J. Constr. Educ. Res. 2008, 4, 177-188. [CrossRef]

8. Ruparathna, R.; Hewage, K. Review of Contemporary Construction Procurement Practices. J. Manag. Eng. 2015, 31, 04014038. [CrossRef]

9. Nadim, W.; Goulding, J.S. Offsite production: A model for building down barriers A European construction industry perspective. Eng. Constr. Archit. Manag. 2011, 18, 82-101. [CrossRef] 
10. Blismas, N.; Wakefield, R. Drivers, constraints and the future of offsite manufacture in Australia. Constr. Innov. 2009, 9, 72-83. [CrossRef]

11. Li, H.X.; Al-Hussein, M.; Lei, Z.; Ajweh, Z. Risk identification and assessment of modular construction utilizing fuzzy analytic hierarchy process (AHP) and simulation. Can. J. Civ. Eng. 2013, 40, 1184-1195. [CrossRef]

12. Pan, W.; Hon, C.K. Modular integrated construction for high-rise buildings. Proc. Inst. Civ. Eng. Munic. Eng. 2018, 1-12. [CrossRef]

13. Nadim, W.; Goulding, J.S. Offsite production in the UK: The construction industry and academia. Archit. Eng. Des. Manag. 2009, 5, 136-152. [CrossRef]

14. Yunus, R.; Yang, J. Improving ecological performance of industrialized building systems in Malaysia. Constr. Manag. Econ. 2014, 32, 183-195. [CrossRef]

15. Hwang, B.G.; Shan, M.; Looi, K.Y. Knowledge-based decision support system for prefabricated prefinished volumetric construction. Autom. Constr. 2018, 94, 168-178. [CrossRef]

16. Larsson, J.; Eriksson, P.E.; Olofsson, T.; Simonsson, P. Industrialized construction in the Swedish infrastructure sector: Core elements and barriers. Constr. Manag. Econ. 2014, 32, 83-96. [CrossRef]

17. Mao, C.; Xie, F.; Hou, L.; Wu, P.; Wang, J.; Wang, X. Cost analysis for sustainable off-site construction based on a multiple-case study in China. Habitat Int. 2016, 57, 215-222. [CrossRef]

18. Modular Building Institute, Modular Advantage for the Commercial Modular Construction Industry: The Offsite Construction Issue, Canada, 2017. Available online: http://www.modular.org/documents/ Modular_Advantage/ModularAdvantage_1Q_2017_DIGITAL.pdf (accessed on 15 April 2019).

19. Goodier, C.; Gibb, A. Future opportunities for offsite in the UK. Constr. Manag. Econ. 2007, 25, 585-595. [CrossRef]

20. Mao, C.; Liu, G.; Shen, L.; Wang, X.; Wang, J. Structural Equation Modeling to Analyze the Critical Driving Factors and Paths for Off-site Construction in China. KSCE J. Civ. Eng. 2018, 22, 2678-2690. [CrossRef]

21. Jaillon, L.; Poon, C.S.; Chiang, Y.H. Quantifying the waste reduction potential of using prefabrication in building construction in Hong Kong. Waste Manag. 2009, 29, 309-320. [CrossRef]

22. Tam, V.W.Y.; Tam, C.M.; Zeng, S.X.; Ng, W.C.Y. Towards adoption of prefabrication in construction. Build. Environ. 2007, 42, 3642-3654. [CrossRef]

23. Yunus, R.; Yang, J. Critical sustainability factors in industrialised building systems. Constr. Innov. 2012, 12, 447-463. [CrossRef]

24. Zakaria, S.A.S.; Gajendran, T.; Rose, T.; Brewer, G. Contextual, structural and behavioural factors influencing the adoption of industrialised building systems: a review. Archit. Eng. Des. Manag. 2018, 14, 3-26. [CrossRef]

25. Sushil, S. Interpreting the interpretive structural model. Glob. J. Flex. Syst. Manag. 2012, 13, 87-106. [CrossRef]

26. Sushil, S. How to check correctness of total interpretive structural models? Ann. Oper. Res. 2018, $270,473-487$. [CrossRef]

27. Gahana, G.C.; Patil, Y.B.; Shibin, K.T.; Prakash, A. Conceptual frameworks for the drivers and barriers of integrated sustainable solid waste management: A TISM approach. Manag. Environ. Qual. 2018, 29, 516-546. [CrossRef]

28. Jayalakshmi, B.; Pramod, V.R. Total Interpretive Structural Modeling (TISM) of the Enablers of a Flexible Control System for Industry. Glob. J. Flex. Syst. Manag. 2014, 16, 63-85. [CrossRef]

29. Xiong, B.; Skitmore, M.; Xia, B. A critical review of structural equation modeling applications in construction research. Autom. Constr. 2015, 49, 59-70. [CrossRef]

30. Moher, D.; Liberati, A.; Tetzlaff, J.; Altman, D.G. Preferred reporting items for systematic reviews and meta-analyses: The PRISMA statement. Ann. Intern. Med. 2009, 151, 264-269. [CrossRef] [PubMed]

31. Newaz, M.T.; Davis, P.R.; Jefferies, M.; Pillay, M. Developing a safety climate factor model in construction research and practice: A systematic review identifying future directions for research. Eng. Constr. Archit. Manag. 2018, 25, 738-757. [CrossRef]

32. Osei-Kyei, R.; Chan, A.P.C. Review of studies on the critical success factors for public-private partnership (PPP) projects from 1990 to 2013. Int. J. Project Manag. 2015, 33, 1335-1346. [CrossRef]

33. Pan, W.; Gibb, A.G.F.; Dainty, A.R.J. Leading UK housebuilders' utilization of offsite construction methods. Build. Res. Inf. 2008, 36, 56-67. [CrossRef] 
34. Warfield, J.N. Developing Interconnection Matrices in Structural Modeling. IEEE Trans. Syst. Man Cybern. 1974, SMC-4, 81-87. [CrossRef]

35. Shibin, K.T.; Gunasekaran, A.; Papadopoulos, T.; Dubey, R.; Singh, M.; Wamba, S.F. Enablers and Barriers of Flexible Green Supply Chain Management: A Total Interpretive Structural Modeling Approach. Glob. J. Flex. Syst. Manag. 2016, 17, 171-188. [CrossRef]

36. Boyer, K.K.; Swink, M.L. Empirical Elephants-Why Multiple Methods are Essential to Quality Research in Operations and Supply Chain Management. J. Oper. Manag. 2008, 26, 337-348. [CrossRef]

37. Shibin, K.T.; Gunasekaran, A.; Dubey, R. Explaining sustainable supply chain performance using a total interpretive structural modeling approach. Sustainable Prod. Consum. 2017, 12, 104-118. [CrossRef]

38. Cohen, W.M.; Nelson, R.R.; Walsh, J.P. Links and Impacts: The Influence of Public Research on Industrial RandD. Manag. Sci. 2002, 48, 1-23. [CrossRef]

39. Hong, Y.; Chan, D.W.M.; Chan, A.P.C.; Yeung, J.F.Y. Critical Analysis of Partnering Research Trend in Construction Journals. J. Manag. Eng. 2012, 28, 82-95. [CrossRef]

40. Tam, V.W.Y.; Fung, I.W.H.; Sing, M.C.P.; Ogunlana, S.O. Best practice of prefabrication implementation in the Hong Kong public and private sectors. J. Cleaner Prod. 2015, 109, 216-231. [CrossRef]

41. Egan, J. Rethinking Construction, Construction Task Force Report for Department of the Environment, Transport and the Regions; Department of Trade and Industry: London, UK, 1998.

42. Pan, W.; Goodier, C. House-Building Business Models and Off-Site Construction Take-Up. J. Archit. Eng. 2012, 18, 84-93. [CrossRef]

43. Jiang, R.; Mao, C.; Hou, L.; Wu, C.; Tan, J. A SWOT analysis for promoting off-site construction under the backdrop of China's new urbanization. J. Cleaner Prod. 2017, 173, 225-234. [CrossRef]

44. Kamar, K.A.M.; Azman, M.N.A.; Nawi, M.N.M. IBS survey 2010: Drivers, barriers and critical success factors in adopting industrialised building system (IBS) construction by G7 contractors in Malaysia. J. Eng. Sci. Technol. 2014, 9, 490-501. [CrossRef]

45. Luo, L.; Shen, G.Q.; Xu, G.; Liu, Y.; Wang, Y. Stakeholder-associated Supply Chain Risks and Their Interactions in a Prefabricated Building Project: A Case Study in Hong Kong. J. Manag. Eng. 2019, 35, 1-14. [CrossRef]

46. Teng, Y.; Mao, C.; Liu, G.; Wang, X. Analysis of stakeholder relationships in the industry chain of industrialized building in China. J. Cleaner Prod. 2017, 152, 387-398. [CrossRef]

47. Nam, C.H.; Tatum, C.B. Leaders and champions for construction innovation. Constr. Manag. Econ. 1997, 15, 259-270. [CrossRef]

48. Arif, M.; Egbu, C. Making a case for offsite construction in China. Eng. Constr. Archit. Manag. 2010, 17, 536-548. [CrossRef]

49. Pan, W.; Gibb, A.F.; Dainty, A.R.J. Perspective of UK housebuilders on the use of offsite modern methods of construction. Constr. Manag. Econ. 2007, 25, 183-194. [CrossRef]

50. Alderton, M. How Modular Construction Could Offer a Lasting Solution in the Affordable Housing Crisis, ArchDaily. 2019, 1-10. Available online: https://www.archdaily.com/913290/how-modular-constructioncould-offer-a-lasting-solution-in-the-affordable-housing-crisis (accessed on 19 March 2019).

51. Chen, Y.; Okudan, G.E.; Riley, D.R. Sustainable performance criteria for construction method selection in concrete buildings. Autom. Constr. 2010, 19, 235-244. [CrossRef]

52. Gibb, A.G.F.; Isack, F. Re-engineering through pre-assembly: Client expectations and drivers. Build. Res. Inf. 2003, 31, 146-160. [CrossRef]

53. Choi, J.O.; Bin Chen, X.; Kim, T.W. Opportunities and challenges of modular methods in dense urban environment. Int. J. Constr. Manag. 2019, 19, 93-105. [CrossRef]

54. Chiang, Y.H.; Hon-Wan Chan, E.; Ka-Leung Lok, L. Prefabrication and barriers to entry-a case study of public housing and institutional buildings in Hong Kong. Habitat Int. 2006, 30, 482-499. [CrossRef]

55. Hong, J.; Shen, G.Q.; Li, Z.; Zhang, B.; Zhang, W. Barriers to promoting prefabricated construction in China: A cost-benefit analysis. J. Cleaner Prod. 2017, 172, 649-660. [CrossRef]

56. Pan, W.; Sidwell, R. Demystifying the cost barriers to offsite construction in the UK. Constr. Manag. Econ. 2011, 29, 1081-1099. [CrossRef]

57. Jaillon, L.; Poon, C.S. Sustainable construction aspects of using prefabrication in dense urban environment: A Hong Kong case study. Constr. Manag. Econ. 2008, 26, 953-966. [CrossRef]

58. Wong, P.S.P.; Zwar, C.; Gharaie, E. Examining the Drivers and States of Organizational Change for Greater Use of Prefabrication in Construction Projects. J. Constr. Eng. Manag. 2017, 143, 04017020. [CrossRef] 
59. Jaillon, L.; Poon, C.S. Advantages and Limitations of Precast Concrete Construction in High-rise Buildings: Hong Kong Case Studies. In Proceedings of the CIB World Building Congress 2007: Construction for Development, Cape Town, South Africa, 14-17 May 2007; pp. 2504-2514. [CrossRef]

60. Arif, M.; Bendi, D.; Sawhney, A.; Iyer, K.C. State of offsite construction in India-Drivers and barriers. J. Phys. Conf. Ser. 2012, 364, 0-8. [CrossRef]

61. Li, Y.Y.; Chen, P.-H.; Chew, D.A.S.; Teo, C.C.; Ding, R.G. Exploration of Critical External Partners of Architecture/Engineering/Construction (Aec) Firms for Delivering Green Building Projects in Singapore. J. Green Build. 2012, 7, 193-209. [CrossRef]

62. Švajlenka, J.; Kozlovská, M.; Spišáková, M. The benefits of modern method of construction based on wood in the context of sustainability. Int. J. Environ. Sci. Technol. 2017, 14, 1591-1602. [CrossRef]

63. Chen, Y.; Okudan, G.E.; Riley, D.R. Decision support for construction method selection in concrete buildings: Prefabrication adoption and optimization. Autom. Constr. 2010, 19, 665-675. [CrossRef]

64. Hammad, A.W.A.; Akbarnezhad, A. Modular vs conventional construction: A multi-criteria framework approach. In Proceedings of the 34th International Symposium on Automation and Robotics in Construction (ISARC 2017), Taipei, Taiwan, 28 June-1 July 2017; pp. 214-220.

65. Azhar, S.; Lukkad, M.Y.; Ahmad, I. An Investigation of Critical Factors and Constraints for Selecting Modular Construction over Conventional Stick-Built Technique. Int. J. Constr. Educ. Res. 2013, 9, 203-225. [CrossRef]

66. Li, Z.; Shen, G.Q.P.; Ji, C.; Hong, J. Stakeholder-Based Analysis of Drivers and Constraints in the Use of Off-Site Construction. In Proceedings of the 2014 International Conference on Construction and Real Estate Management: Smart Construction and Management in the Context of New Technology, ICCREM 2014, Kunming, China, 27-28 September 2014; pp. 26-36. [CrossRef]

67. Arditi, D.; Ergin, U.; Gunhan, S. Factors Affecting the Use of Precast Concrete Systems. J. Archit. Eng. 2000, 6, 79-86. [CrossRef]

68. Yunus, R.; Suratkon, A.; Wimala, M.; Abdul Hamid, H.; Mohd Noor, S.R. Motivational Factors on Adopting Modular Coordination Concept in Industrialized Building System (IBS). MATEC Web Conf. 2016, 47, 04017. [CrossRef]

69. Gibb, A.G.F. Off-site Fabrication: Prefabrication, Pre-assembly and Modularization; Whittles Publishing: Scotland, UK, 1999. [CrossRef]

70. Yunus, R.; Noor, S.R.M.; Abdullah, A.H.; Nagapan, S.; Hamid, A.R.A.; Tajudin, S.A.A.; Jusof, S.R.M. Critical Success Factors for Lean Thinking in the Application of Industrialised Building System (IBS). IOP Conf. Ser. Mater. Sci. Eng. 2017, 226, 012045. [CrossRef]

71. Mao, C.; Shen, Q.; Shen, L.; Tang, L. Comparative study of greenhouse gas emissions between off-site prefabrication and conventional construction methods: Two case studies of residential projects. Energy Build. 2013, 66, 165-176. [CrossRef]

72. Yunus, R.; Yang, J. Legislative Challenge to Sustainable Application of Industrialized Building System (IBS). J. Technol. 2016, 78, 45-55. [CrossRef]

73. Quale, J.; Eckelman, M.J.; Williams, K.W.; Sloditskie, G.; Zimmerman, J.B. Construction Matters Comparing Environmental Impacts of Building Modular and Conventional Homes in the United States. J. Ind. Ecol. 2012, 16, 243-253. [CrossRef]

74. Slaughter, E.S. Models of Construction Innovation. J. Constr. Eng. Manag. 1998, 124, 226-231. [CrossRef]

75. Richard, R.B. Industrialised building systems: Reproduction before automation and robotics. Autom. Constr. 2005, 14, 442-451. [CrossRef]

76. Richard, R.B. Industrialized, flexible and demountable building systems: Quality, economy and sustainability. In Proceedings of the Criocm 2006 International Symposium on Advancement of Construction Management and Real Estate, Beijing, China, 3-5 November 2006; pp. 1-11.

77. Arif, M.; Goulding, J.; Rahimian, F.P. Promoting Off-Site Construction: Future Challenges and Opportunities. J. Archit. Eng. 2012, 18, 75-78. [CrossRef]

78. McGraw Hill Construction, Safety Management in the Construction Industry: Identifying Risks and Reducing Accidents to Improve Site Productivity and Project ROI, Bedford, MA, 2013. Available online: https://www. cpwr.com/sites/default/files/publications/SafetyManagementinConstructionSMR-2013_0.pdf (accessed on 30 January 2019).

79. Mao, C.; Shen, Q.; Pan, W.; Ye, K. Major Barriers to Off-Site Construction: The Developer's Perspective in China. J. Manag. Eng. 2014, 31, 04014043. [CrossRef] 
80. Dubey, R.; Ali, S.S. Identification of flexible manufacturing system dimensions and their interrelationship using total interpretive structural modelling and fuzzy MICMAC analysis. Glob. J. Flex. Syst. Manag. 2014, 15, 131-143. [CrossRef]

81. Whetten, D.A. What Constitutes a Theoretical Contribution? Acad. Manag. Rev. 1989, 14, 490-495. [CrossRef]

(C) 2019 by the authors. Licensee MDPI, Basel, Switzerland. This article is an open access article distributed under the terms and conditions of the Creative Commons Attribution (CC BY) license (http://creativecommons.org/licenses/by/4.0/). 